\title{
USING OF THERMOSIPHON SOLAR COLLECTOR IN AN AIR HEATING SYSTEM OF PASSIVE HOUSE
}

\author{
${ }^{1}$ Vasyl ZHELYKH, ${ }^{2}$ Christina KOZAK, ${ }^{3}$ Olena SAVCHENKO \\ Department Heat, Gas Supply and Ventilation, Institute of Building and Environmental \\ Engineering, Lviv Polytechnic National University, Stepan Bandera str. 12, Lviv-13, Ukraine, \\ e-mail: ${ }^{3}$ o.savchenko@i.ua
}

Received 20 October 2015; accepted 18 January 2016

\begin{abstract}
In this article the using of thermosiphon solar collectors for system air heating of premises of passive houses was examined. The research determination the air velocity and air temperature in the space of experimental module were conducted. According to the research the field of temperature and air velocity in the space of the experimental module for different output of thermal solar radiation were built. The main factors that affect the value of speed and temperature of the internal air were identified. It was established that the presence of spiral turbo baffles increases the thermal output of thermosiphon collector to $15 \%$, and the rate of heated flow to $17 \%$
\end{abstract}

Keywords: Thermosiphon solar collector, Velocity of the internal air, Temperature of the internal air, Air heating system, Passive house

\section{Introduction}

Present and future of energy Ukraine is uniquely associated with the use of alternative energy sources. This using of renewable energy allows reducing the use of traditional energy resources. One of the main areas of solar energy, biomass energy and low potential of soil is their attraction to receiving of the heat energy in systems heating, ventilation and hot water. So, scientists of the Department Heat, Gas Supply and Ventilation, Lviv Polytechnic National University have developed and explored several designs of solar collectors and design of biogas plant that allow reducing the use of imported fuel [1], [2], [3], [4] However, in the winter of heat energy from alternative sources, which can be used in heating systems, in temperate conditions is insufficient. 
That is why at present scientists of the department are considering options for combined heating supplies systems, which can simultaneously to use the heat energy from conventional fuels and from alternative sources. For example, pre-heating the outside air at the ground-air heat exchangers of the geothermal ventilation system [5] or using of infrared heaters in the combined systems heating supplies of premises of production buildings are studied [6]. One of the current research areas is the development of heating supplies systems using the thermosiphon solar collector.

\section{Aim of work}

Explore the specifics of changing meteorological parameters inside air during work thermosiphon solar collector and the air heating system in a passive house.

\section{Analysis of existing studies}

As known, passive houses consume minimum energy for maintaining life support systems of people. Reducing energy consumption is due to the use of several mandatory requirements for the design and location of a passive house. The first requirement in the design is the use of effective insulating materials in the construction of external protections: heat transfer coefficient of external protections shall be not greater than $0.15 \mathrm{~W} /\left(\mathrm{m}^{2} \cdot \mathrm{K}\right)$. The construction of the windows should have a triple glazing with two low-emission coatings and filling of inert gas, should insulated window frames, heat transfer coefficient of window shall be not greater than $0.8 \mathrm{~W} /\left(\mathrm{m}^{2} \cdot \mathrm{K}\right)$. During the creating of design and location of the house the architects plan some solutions for reduce energy use [7]. In particular, when designing a passive house compact building should create and the external protections are recommended to orient to the south.

Life support systems include systems of heating, ventilation and hot water. There are also certain requirements for them:

- $\quad$ use of solar energy;

- use of air-to-air heat exchanger in the mechanical ventilation system;

- pre-heating of outside air for ventilation system;

- use solar energy for heating water.

The use of solar energy in passive house is used for heating of premises. In passive houses there are two types of using of solar energy for premises heating: direct and indirect solar heating [8]. Direct solar heating of passive houses carried out by expense the inflow of receipts solar radiation through the windows, which are located on the south facade. Direct solar heating is considered the easiest way to space heating, which reduces the load on the heating system in the cold season. Therefore, when designing a passive house, orientation of windows to the south and avoidance of shading of the southern facade are importantly.

A Trombe wall and air solar heaters are used for indirect solar heating of premises [9]. A Trombe wall consists of array wall and glass partitions installed at some distance from the outside part of the wall. The wall is made of a material that has a high 
accumulative ability (concrete, brick, and stone). To increase the efficiency of absorption wall is painted in dark color or is covered by a selective coating. The solar heat coming into the room through the glass partition is flagged to wall and is accumulated in it. At night, an array of walls gives off heat into the room, allowing maintain the internal parameters of indoor air when the sunlight is absent. Availability of Trombe wall impairs natural lighting and not allows adjusts the heat receipts the premises from the wall.

The air solar heaters that are using in indirect solar heating usually work on a thermosiphon principle. The phenomenon of free convection is used. Air solar collectors have a simple design that allows combine them with the construction of the roof. They start work at outdoor temperatures $25-30{ }^{\circ} \mathrm{C}$ that are lower than the temperature for water solar collectors. Air solar collectors should be used in air heating, in which, for reducing capital costs the air ducts are not used. In this case a system of the solar collector is set in the roof of heated premise, and the entrance and exit of air carried out through holes in the bottom of the collector.

For heating premises of passive house the authors developed and patented design of the thermosiphon collector [10], incision which is shown in Fig. 1.

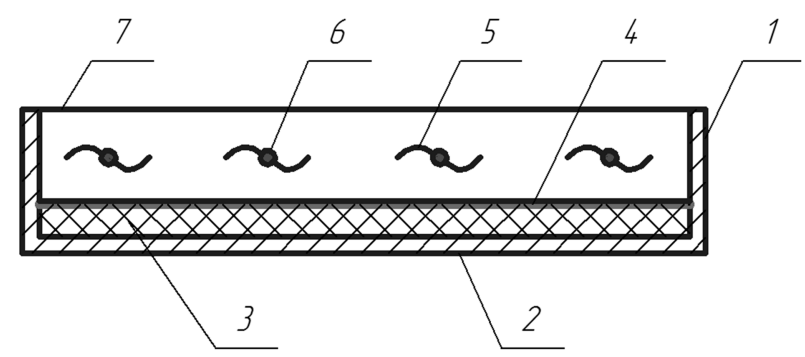

Fig. 1. The incision of thermosiphon collector,

1 - lateral wall of corps; 2 - bottom of corps; 3 - layer insulation material; 4 - heat-absorbing plate; 5 - spiral turbo baffles; 6 - metal rod; 7 - light-penetrating plate

The presence of spiral turbo baffles, which were made of black material, and the presence of additional layer of insulation are feature of design thermosiphon collector (Fig. 1). Spiral turbo baffles curved around the metal rod and can be rotated around it. Availability of spiral turbo baffles allows stirs the air flow and, consequently, increase it speed and heat transfer.

For effectively maintain the necessary microclimate parameters, thermosiphon collector should be used to heat the mansard premises of passive houses. Thus, the solar collector is installed as part of the sloping roof constructions oriented to the south; a bottom of the solar collector at the same time serves as a ceiling of mansard premise (Fig. 2). This system requires no additional air ducts; it can reduce the cost of heating system.

Thermosiphon solar collector works as follows. The cold internal air enters through the entrance hole in solar collector, moves around heat-absorbing plate and is heated up. At the expense the temperature difference the heated internal air rises to the entrance hole and enters to premises. The spiral turbo baffles that provided for in construction of 
thermosiphon collector allow intensifying the process of heat transfer from the heatabsorbing plate to the air in the middle of the collector.

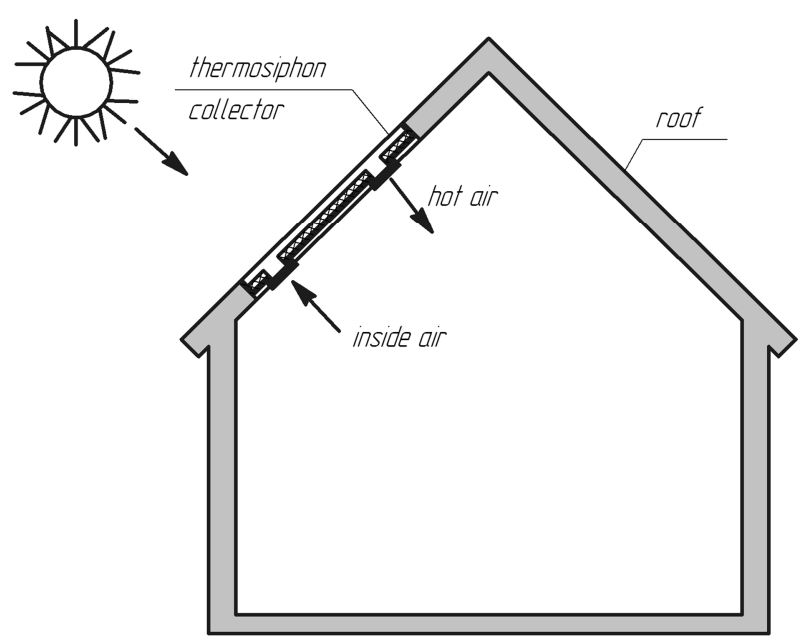

Fig. 2. Setting of thermosiphon collector on the roof

Air consumption, and therefore air speed, which is passing through the collector, is regulated by adjusting device.

\section{Experimental studies}

Meteorological parameters describing microclimate of premises are temperature, relative humidity and speed of the internal air. The simultaneous effect of these factors on human health must take into account when operating air heating. In particular, the presence of air motion in the room facilitates heat transfer from the human body and positively influences on the livelihoods of people. Microclimate parameters defined in the work zone, namely in the area of $0.15 \mathrm{~m}$ from the floor and $1.8 \mathrm{~m}$ in height and at a distance of not less than $0.15 \mathrm{~m}$ from the wall. According to Ukrainian standards [11] during the cold period for living rooms optimal values of the specified parameters are: internal air temperature should equal to the value out of range of $22.0 \pm 2.0^{\circ} \mathrm{C}$ and air motion velocity $-0.1-0.3 \mathrm{~m} / \mathrm{s}$.

Using of thermosiphon collector in air heating system allows support the allowable values of temperature and speed air indoors.

For the study of microclimate parameters that provides a thermosiphon collector the hermetic experimental module with volume of $10.8 \mathrm{~m}^{3}$, which imitated mansard living room was created (Fig. 3).

The electric infrared heater was used to simulate solar thermal radiation; heat radiation intensity is varied in the experimental studies. 


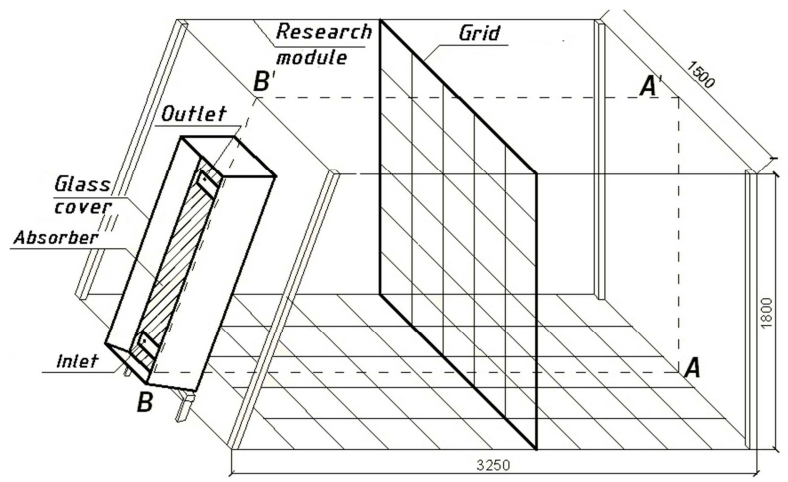

Fig. 3. General view of the experimental module (premises)

Studies were conducted on the experimental setup, shown in Fig. 4. The planning of experiment was used for execution the necessary and sufficient number of experiments. The temperature and speed of internal air in module volume were chosen by the optimization parameters. The area of inlet and outlet manifold $F\left[\mathrm{~m}^{2}\right]$, intensity infrared heat radiation heater $I\left[\mathrm{~W} / \mathrm{m}^{2}\right]$, the angle of inclination of solar collector $\alpha$ are variables. The entire volume of the module was divided grid $30 \times 30 \mathrm{~cm}$ for accuracy of measurements. The temperature of the internal air volume of the module, the velocity of the internal air in the volume of the module, the temperature and air velocity in the inlet and outlet of the solar collector, the intensity of the infrared heater radiation, temperature of heat-absorbing plate and temperature of glass surface of collector were determined during the experimental research. Measuring these quantities was carried out by such devices: pyranometer 3, [12] thermometer 4 and pyrometer 5 . Number of measurements is determined according to the planning experiment matrix.

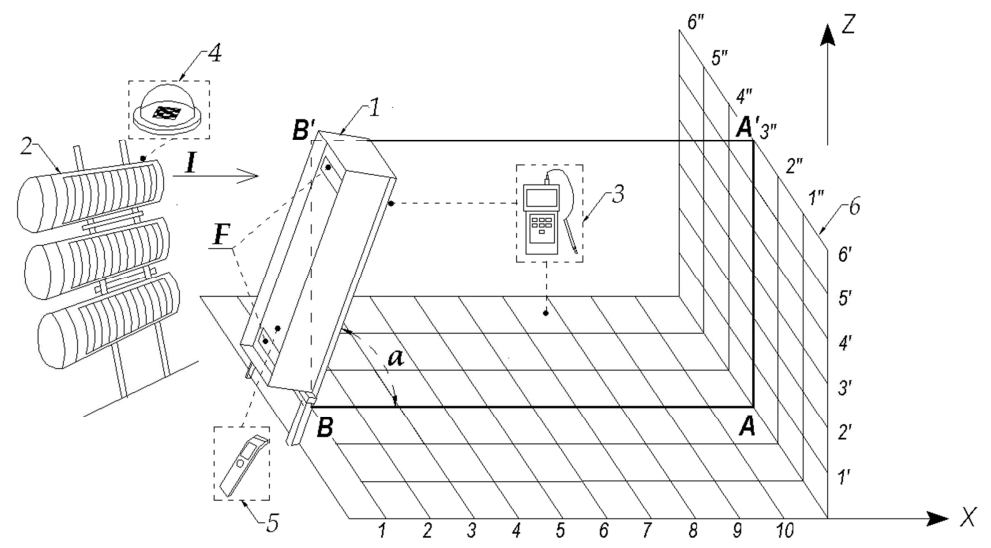

Fig. 4. Experimental installation

1 - research thermosiphon collector; 2 - infrared heater; 3 - pyranometer; 4 - thermo-anemometer ATT-1004; 5 - infrared pyrometer Nimbus-530; 6 - grid; ABA'B' $^{\prime}$ - plane in the area of radiation 
The results determine the internal air temperature in the experimental module are presented in the form of isotherms and are shown in Fig. 5.

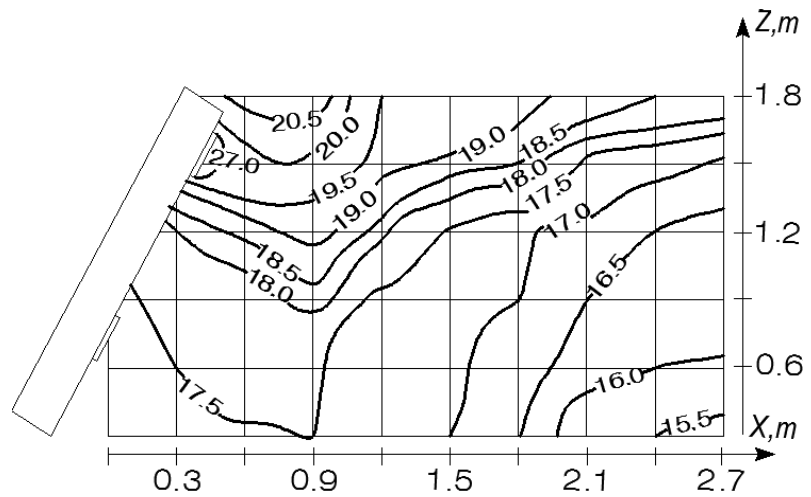

a)

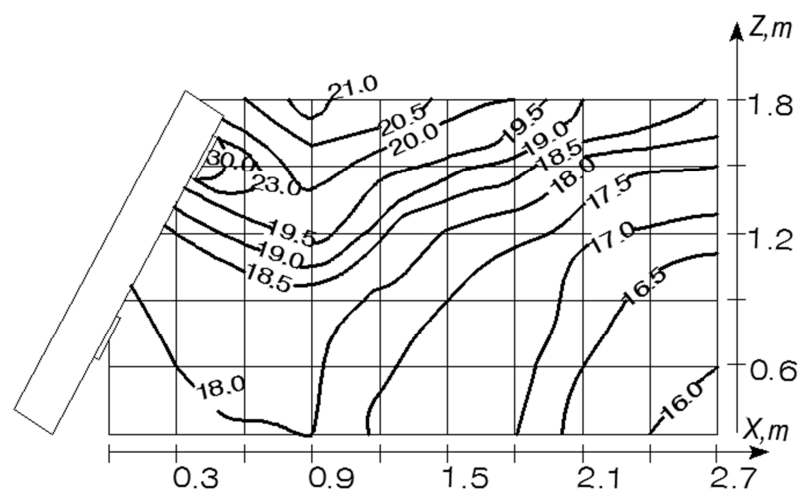

b)

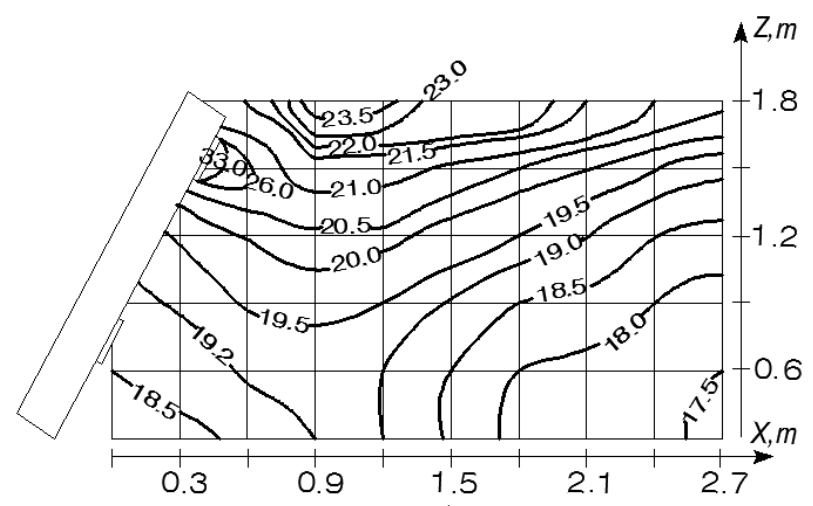

c)

Fig. 5. The temperature fields in the experimental module a) $I=155 \mathrm{~W} / \mathrm{m}^{2}$; b) $I=185 \mathrm{~W} / \mathrm{m}^{2}$; c) $I=220 \mathrm{~W} / \mathrm{m}^{2}$ 
As it is shown in Fig. 5, with increasing radiation intensity infrared heater increases the temperature of inside air in the module. In addition, the temperature distribution in the module is quite uneven, and the numerical values of the temperature are less than the standardized values of inside air temperature for the cold season.

Two part experiments were conducted for determination the impact of spiral turbo baffles on the value of air velocity in the experimental modules. In the first part (Fig. 6) studies thermosiphon collector without spiral turbo baffles were carried out, the second part of the experiments shows the change in value of the air velocity in the presence of spiral turbo baffles in the collector (Fig. 7).

The velocity of the air in the experimental module was determined at different values of the thermal radiation intensity, area of holes solar collector and angle of collector installation. Fields velocities of internal air in experimental module without spiral turbo baffles are presented in Fig. 6.

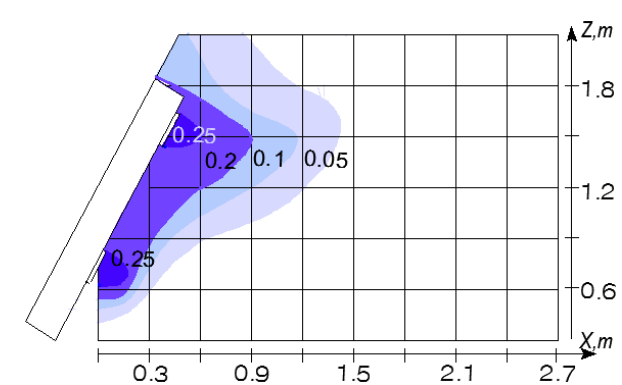

a)

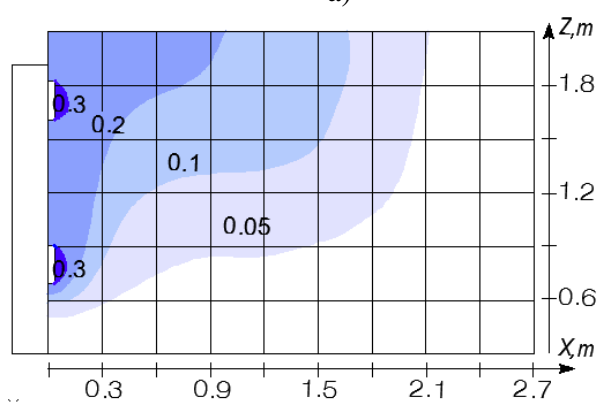

c)

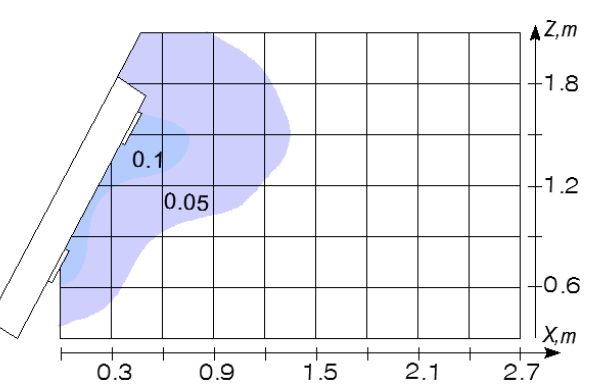

b)

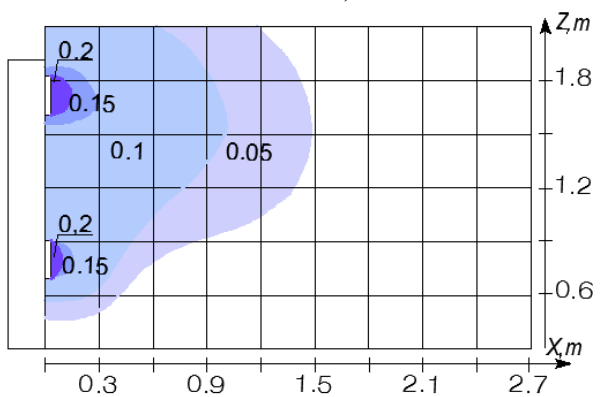

d)

Fig. 6. The fields of airspeed in the experimental modules without spiral turbo baffles a) $\alpha=65^{\circ} ; I=850 \mathrm{~W} / \mathrm{m}^{2} ; F=0.063 \mathrm{~m}^{2} ;$ b) $\alpha=65^{\circ} ; I=155 \mathrm{~W} / \mathrm{m}^{2} ; F=0.021 \mathrm{~m}^{2}$; c) $\alpha=90^{\circ} ; I=850 \mathrm{~W} / \mathrm{m}^{2} ; F=0.063 \mathrm{~m}^{2} ;$ d) $\alpha=90^{\circ} ; I=155 \mathrm{~W} / \mathrm{m}^{2} ; F=0.021 \mathrm{~m}^{2}$

As it is shown in Fig. 6, the intensity of thermal radiation that enters the collector and angle setting solar collector greatly affect the value and distribution of velocity inside air into the room. To ensure air movement in large volume of experimental module advisable thermosiphon collector set at an angle of $90^{\circ}$.

In Fig. 7 there is presented the velocity fields of internal air in the experimental module in the presence of spiral turbo baffles in the solar collector. 


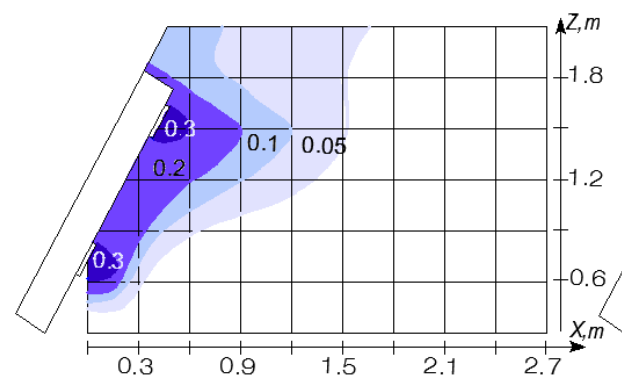

a)

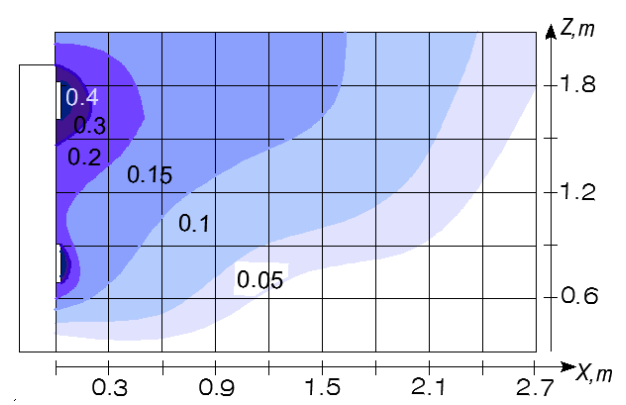

c)

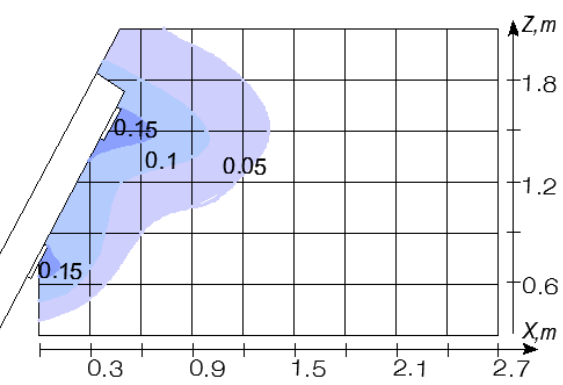

b)

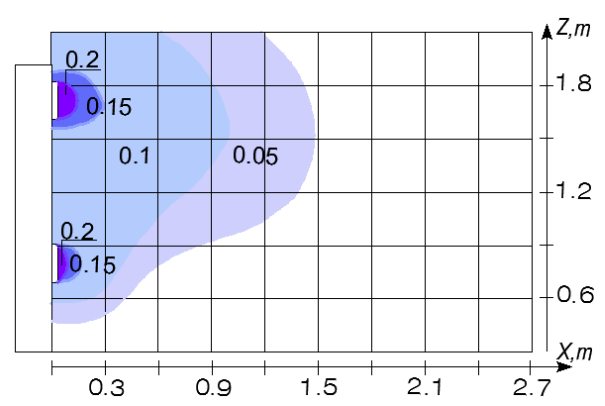

d)

Fig. 7. The fields of airspeed in the experimental modules with spiral turbo baffles a) $\alpha=65^{\circ} ; I=850 \mathrm{~W} / \mathrm{m}^{2} ; F=0.063 \mathrm{~m}^{2}$; b) $\alpha=65^{\circ} ; I=155 \mathrm{~W} / \mathrm{m}^{2} ; F=0.021 \mathrm{~m}^{2}$; c) $\alpha=90^{\circ} ; I=850 \mathrm{~W} / \mathrm{m}^{2} ; F=0.063 \mathrm{~m}^{2} ;$ d) $\alpha=90^{\circ} ; I=155 \mathrm{~W} / \mathrm{m}^{2} ; F=0.021 \mathrm{~m}^{2}$

As it is shown in Fig. 6 and in Fig. 7, the value of speed of internal air in the module is fairly small and do not exceed the standardized values. The area of input and output holes of collector have the greatest influence on the velocity of the jet of heated air. By increasing the area of holes from 0.02 to $0.06 \mathrm{~m}^{2}$ the value of jet speed is increasing by $20 \%$ for all other constant parameters. In addition, installation of spiral turbo baffles increases the thermal power of thermosiphon collector on $15 \%$, and the speed of warm air $-17 \%$.

Technical characteristics of the instruments, which were carried out measurements in research:

- Heat-loss anemometer ATT-1004: the range of speed measurement $0.2-20 \mathrm{~m} / \mathrm{s}$, the resolution $0.1 \mathrm{~m} / \mathrm{s}$, the accuracy $\pm(0.2-0.05) \mathrm{V}$, the range of temperature measurement $0-50{ }^{\circ} \mathrm{C}$; the measurement accuracy $0.1^{\circ} \mathrm{C}$;

- Pyrometer Nimbys-530/1: the range of measurement $(-32)-(+530)^{\circ} \mathrm{C}$, the resolution $0.1^{\circ} \mathrm{C}$, the accuracy $\pm 1^{\circ} \mathrm{C}$;

- Pyranometer M-80 m: the absolute uncertainty of measurement $\pm 20 \mathrm{~W} / \mathrm{m}^{2}$, the fractional minimum accuracy $0.2 \%$, the fractional maximum accuracy $0.37 \%$. 


\section{Conclusion}

As studies have shown, the thermal energy, that a thermosiphon solar collector can give, are enough for maintain the parameters of the microclimate in the premises. In cold season, the thermosiphon solar collector must use in combination with other heating systems. Therefore, passive houses should use the combined heating supplies system, including using thermosiphon solar collectors for provide thermal comfort. The obtained results can be used in the design of heating and ventilation systems of buildings with mansard

\section{References}

[1] Shapoval S., Datcko O., Omelchuk O. Receipts of solar energy to triple-oriented system of solar collectors, Proceedings of the National University 'Lviv Polytechnic', Theory and practice of building, Lviv, Ukraine, 2012, No. 737, pp. 226-230.

[2] Voznyak O., Kasynets M., Shapoval S. Improving of the room heat regime at the solar panel using, Investigation efficiency of the combined solar system of heat supply with heataccumulating, MOTROL, Commission of Motorization and Energetics in Agriculture, Lublin-Rzeszòw, Poland, Vol. 14, No 6, 2012, pp. 7-13.

[3] Zhelykh V., Piznak B. The experimental studies of polymer solar collector, Proceedings of the National University 'Lviv Polytechnic', Theory and practice of building, Lviv, Ukraine, 2012, No. 737, pp. 112-116.

[4] Zhelykh V., Kapalo P., Furdas Yu. Thermal characteristics of household bioreactor. Proceedings of the Third Annual International Conference of the Construction 'The structure of the building tendency 2013 'Ecology, energy, security, stability', Ostrava, Slovakia, 7-8 November 2013, pp. 266-271.

[5] Zhelykh V., Savchenko O., Matusevych V. The application features geothermal ventilation of the passive house in the cold season, Book of abstracts, $X V$ International Scientific Conference 'Current issues of civil and environmental engineering and architecture', Rzeszow, Poland, 9-11 September 2015, pp. 152-153.

[6] Zhelykh V., Spodyniuk N., Dzeryn O., Shepitchak V. Specificity of temperature mode formation in production premises with infrared heating system, IJEIT, International Journal of Engineering and Innovative Technology, Vol. 4, No. 9, 2015, pp. 8-16.

[7] Baranyai B., Kistelegdi I. Energy management monitoring and control of public building, Pollack Periodica, Vol. 9, No. 2, 2014, pp. 77-88.

[8] Chel A., Nayak J. K., Kaushik G. Energy conservation in honey storage building using Trombe wall, Energy and Buildings, Vol. 40, 2008, pp. 1643-1650.

[9] Holloway D. R. A simple design methodology for passive solar architecture, Architecture Solar Virtual Reality Native American Archaeology, 2005, pp. 1-15, http://www. spatial design.info/blog/wp-content/uploads/2007/12/Architecture-Solar-Virtual-Reality.pdf, (last visited 30 September 2013).

[10] Zhelykh V., Lesik Chr. Patent for utility model of Ukraine, No. 68773, Thermo-siphon solar collector, 10 April 2012, Bulletin No. 7.

[11] SBC V.2.5-67-2013, Heating, ventilation and air conditioning, Kyiv, Ukraine, 2013.

[12] Skuratovich I. M., Lutsko L. V., Klivantsova V. A., Kazeyeu Y. I. Actinometric instruments for automated systems, WMO Technical Conference on Meteorological and Environmental. Instruments and Methods of Observation (TECO-2005), Bucharest, Romania, 4-7 May 2005, Section 1, Paper 2. 